\title{
TOURISM AS A LONG-RUN ECONOMIC GROWTH FACTOR: THE SPANISH CASE
}

\section{Jacint Balaguer and Manuel Cantavella-Jordá*}

\author{
WP-EC 2000-10
}

Correspondencia a J. Balaguer: Instituto de Economía Internacional. Departament d'Economia. Universitat Jaume I. Campus del Riu Sec. 12071 Castelló (Spain). Tel. +34 964728612 / Fax. +34 964728591 / E.mail. coll@eco.uji.es

Editor: Instituto Valenciano de Investigaciones Económicas

Primera Edición Junio 2000

Depósito Legal: V-2576-2000

Los documentos de trabajo del IVIE ofrecen un avance de los resultados de las investigaciones económicas en curso, con objeto de generar un proceso de discusión previo a su remisión a las revistas científicas.

*Instituto de Economía Internacional y Departamento de Economía, Universitat Jaume I. 


\title{
TOURISM AS A LONG-RUN ECONOMIC \\ GROWTH FACTOR: THE SPANISH CASE
}

Jacint Balaguer y Manuel Cantavella-Jordá

\begin{abstract}
A B S T R A C T
This paper examines the role of tourism in the Spanish long-run economic development. The tourist-led growth hypothesis is tested. The results indicate that, at least, during the last three decades economic growth in Spain has been sensible to persistent expansion of international tourism. The increase of this activity has produced multiplier effects over time. External competitivity has also been proved in the model to be a fundamental variable for Spanish economic growth in the long run. From the empirical analysis it can be inferred the positive effects on income that government policy, in the adequacy of supply as well as in the promotion of tourist activity, may bring about.
\end{abstract}

Key words: economic growth, international tourism, multiplier effects

\section{R E S U M E N}

Este trabajo aporta evidencia acerca de la importancia de los ingresos de divisas por turismo en el crecimiento económico español experimentado en las últimas tres décadas. Los resultados econométricos indican que existe una relación de largo plazo entre el crecimiento de la renta del país y los ingresos procedentes del turismo internacional. Esta relación econométrica es única, y pone de relieve que la actividad turística tiene importantes efectos multiplicadores. Adicionalmente, se pone de relieve que la competitividad externa, cuyos efectos sobre el crecimiento económico son notablemente significativos, debe ser tenida en consideración a la hora de formular una relación a largo plazo. A la luz de los resultados obtenidos, cabe esperar que las distintas políticas publicas tanto en la adecuación de la oferta como en la promoción de la actividad turística puedan tener efectos beneficiosos sobre la renta.

Palabras clave: crecimiento económico, turismo internacional, efectos multiplicadores 


\section{INTRODUCTION}

A distinctive feature of Spain is its importance as an international tourist destination as well as the relative weight that foreign exchange income has in its economy. ${ }^{1}$ As a matter of fact, the earnings from tourism have systematically compensated Spanish trade imbalances since the seventies. In view of this situation, the economists have very often taken for granted that the inflow of foreign exchange for this concept would stimulate a country's economic development. Nevertheless, this hypothesis has not been yet tested and therefore it may be interesting to analyse whether it is empirically significant or not over time. ${ }^{2}$

Several decades of tourist expansion in Spain may probably represent enough time to examine if international tourism growth has significantly contributed to the country's economic development. The analysis should go beyond its own multiplier effects. ${ }^{3}$ Thus, the main objective of this paper is to asses whether and, if so, to what extent Spanish economic growth responds to the evolution of external tourist activity during the 1975-1997 period. The background on this question is referred to the literature of the export-led growth hypothesis and to recent theoretical models which only consider non-traded goods such as tourism. ${ }^{4}$

As in the export-led growth hypothesis, a tourist-led growth hypothesis would postulate the existence of various arguments for which tourism would become a main determinant of overall long-run economic growth. In a more traditional sense it should be argued that tourism brings in foreign exchange which can be used to import capital goods in order to produce goods and services, leading in turn to economic growth. ${ }^{5}$ In other words, it is possible that tourists provide a remarkable part of the necessary financing for the country to import more than to export. If those imports are capital goods or basic inputs for producing goods in any area of the economy, then, one can say that earnings from tourism are playing a

\footnotetext{
1 The United States remains as the main perceptor of international tourist revenues. Italy and France are the following important tourist countries as far as foreign exchange earnings from tourism is concerned. It is important to take into consideration that the relative weight of tourism in the economy of these three countries is smaller than the one in Spain. During 1996 for example, the profits on tourist transactions represented 0.9\% of the United States's gross domestic product (GDP), $1.9 \%$ of France's and $2.5 \%$ of Italy's whereas for Spain they represented $4.8 \%$ of its GDP (World Tourism Organization).

${ }^{2}$ See, for example, Padilla (1988).

${ }^{3}$ Short-run effects can be seen in Sinclair (1982).

${ }^{4}$ Most economists have been working with variables related to traded goods and economic development. As a matter of fact, a large number of empirical studies have focused on the causal relationship between exports and economic growth : These studies have reported mixed results. A selection of relevant papers in this area includes Ahmed and Kwan (1991), Kwan and Cotsomotis (1991), Jin (1995), Xu (1996), Thornton (1997).

${ }^{5}$ See McKinnon (1964).
} 
fundamental role in economic development. Obviously, non-tourist regions will also benefit from it as a result of the distribution of a country's wealth.

On the other hand, international tourism would contribute to an income increase at least in two additional ways as the export-led growth hypothesis postulates. In the first place, enhancing efficiency through increased competition among firms and others international tourist destinations (Bhagwati and Srinivasan, 1979; Krueger, 1980), and in the second place, facilitating the exploitation of economies of scale in local firms (Helpman and Krugman, 1985).

Taking into account that a large proportion of a tourist's expenditure is spent on the consumption of non-traded goods and services in the host country, there exist factors which can have either a positive role or an unfavourable impact on economic growth. Non-traded goods and services are not exportables in the traditional sense because their price is not determined in the international market, but in the local market. Obviously, tourists' consumption of non-traded goods and services has a impact on the relative price and availability of the non-traded goods and services for the domestic consumer. As the price in the tourist-receiving country, is determined by forces of foreign demand, local demand and supply, a model with monopoly power in price determination may be constructed to analyse the impact of tourism.

In the static framework, there are at least two analytical papers which examine the relationship between tourism and welfare where tourists consume non-traded goods and services. In the first paper, Hazari and $\mathrm{Ng}$ (1993) show that in a monopoly power framework, tourism may be welfare reducing. In the second paper, Hazari and Kaur (1993) argue that in a Komiya (1967) type first-best model, tourism is always welfare improving.

More recently, Hazari and Sgro (1995) developed a dynamic model in which a favourable impact of a buoyant world demand for tourism would have a positive effect on the long-run growth of a small economy. This favourable impact is generated by tourism behaviour as a time-saving device which allows domestic population to consume now rather than later due to the requirement of a lower saving rate.

The remainder structure of this paper is organised as follows. In section II, a tourism growth model is presented. Section III discusses the employed methodology and results. Section IV provides the main conclusions of the analysis. 


\section{MODEL SPECIFICATION AND TIME SERIES ANALYSIS}

In order to explain the growth rate of output over long periods one is usually referred to a couple of complementary approaches. One is growth theory, which models the interactions among factor supplies, productivity growth, saving, and investment in the process of growth. The other is growth accounting, which attempts to quantify the contribution of different determinants of output growth. Most papers, have been concentrated on the so-called export-led growth hypothesis for both developing and industrialised countries. However, the objective of this article, as it was indicated before, is to analyse the role of tourism for the economic growth in Spain. The hypothesis that tourism in Spain is a major determinant of long-run growth is, then, tested. The model includes gross domestic product, tourism, and exchange rate. Based upon the assumption that Spain is a small open economy, these are the minimum and more relevant variables that have been considered. ${ }^{6}$ In econometric terms the equation is as follows :

$\log Y_{t}=\alpha_{0}+\alpha_{1} \log$ TOUSA $_{t}+\alpha_{2} \log q_{t}+u_{t}$

$\mathrm{t}=1975 \mathrm{Q} 1 \ldots 1997 \mathrm{Q} 1$

1975Q1 stands for the first quarter of 1975; analogously for 1997Q1.

Since $Y$, TOUSA and $q$ are expressed in natural logarithms, the coefficients of the last two variables are elasticities; $Y$ is real gross domestic product; TOUSA is international tourism earnings in real terms, $q$ is the real effective exchange rate $;^{7} u$ is the error term which represents omitted factors left out by the deterministic part of the model (see Appendix for more details about variables). ${ }^{8}$

The problem with equation 1 could arise as a consequence of the spurious regression phenomenon first described by Granger and Newbold (1974). This is due to non-stationary trends in time series data. The mean, variance, and autocorrelation of the series are in general non-constant through time, the coefficient of determination $\left(R^{2}\right)$ may simply capture correlated trends and low Durbin-Watson (DW) statistics may reflect non-stationary residuals.

\footnotetext{
${ }^{6}$ One should think that for the long-run analysis between economic growth and tourism the number of variables should be held to a minimum. The reason is that the more variables included in the model the higher the likelihood to obtain more than one relationship in the long run. From the economic point of view this situation might appear somewhat confusing.

${ }^{7}$ This is a proxy variable of external competitivity. It should be fundamental when analysing the rapid growth of Spanish income especially since they joined the EEC in 1986.

${ }^{8}$ TOUSA is a variable that has been seasonally adjusted. Sutcliffe and Sinclair (1980) presents a seasonality measure for this variable.
} 
In this case, as Phillips (1986) argues, OLS estimates do not converge to constants and the standard $t$ and $F$ statistics do not even have the limiting distributions. In view of this concern, one has to investigate whether a series is stationary in levels, $I(0)$, or stationary in differences, $I(1), I(2), \ldots I(n)$, in order to apply the correct methodology, avoiding any spurious inferences. ${ }^{9}$

Before the long-run relationship between tourism and growth in Spain can be determined it is important to carry out a univariate analysis. Testing stationarity of time series leads to the implementation of the econometric model using the appropriate methodology. The stationarity of the series was investigated by employing the unit root tests developed by Dickey and Fuller $(1979,1981)$, and Phillips and Perron (1988). ${ }^{10}$ Knowing that unit root tests are sensitive to the presence of deterministic regressors, three models were estimated. The most general model with a drift and time trend was estimated first, and restrictive models, that is, with a drift and without either drift and trend, respectively, were estimated thereafter. Unit root tests for each variable, then, was performed on both levels (Table 1) and first differences of variables (Table 2).

Table 1 shows the different tests statistics with regard to the null hypothesis of one unit root against the stationary alternative. The most general model indicates that the null cannot be rejected for each variable and therefore a unit root might exist. Looking at Table 2 it can be observed that $\Delta \log Y, \Delta \log$ TOUSA and $\Delta \log q$ reject an $I(1)$ series in differences $(I(2)$ in levels) against the alternative of an $I(O)$ series in differences $(I(1)$ in levels). Thus, the data generation process examination suggests that the use of cointegration techniques will be suitable to proceed with the long-run analysis.

\footnotetext{
${ }^{9}$ An $I(n)$ variable means that the original series has been differenced $n$ times to become stationary $(n$ is called order of integration).

${ }^{10}$ An $I(n)$ variable means that the original series has been differenced $n$ times to become stationary $(n$ is called order of integration).
} 
Table 1. Augmented Dickey-Fuller and Phillips Perron Unit root Tests (levels)

\begin{tabular}{ccccc}
\hline Statistics & $\log Y$ & $\log$ TOUSA & $\log q$ & $\begin{array}{c}\text { Critical values } \\
90 \% \text { and } 95 \%\end{array}$ \\
\hline$\tau_{\tau(\mathrm{ADF})}$ & $-1.87(2)$ & $-1.74(2)$ & $-2.14(2)$ & $-3.15 /-3.46$ \\
$\tau_{\mu(\mathrm{ADF})}$ & $0.099(2)$ & $-0.28(2)$ & $-2.36(2)$ & $-2.58 /-2.89$ \\
$\tau_{(\mathrm{ADF})}$ & $2.65(2)$ & $2.22(2)$ & $0.42(2)$ & $-1.16 /-1.94$ \\
$\tau_{\tau(\mathrm{PP})}$ & $-1.40(3)$ & $-3.31(3)$ & $-2.19(3)$ & $-3.15 /-3.46$ \\
$\tau_{\mu(\mathrm{PP})}$ & $0.38(3)$ & $-0.69(3)$ & $-2.30(3)$ & $-2.58 /-2.89$ \\
$\tau_{(\mathrm{PP})}$ & $6.2(3)$ & $1.58(3)$ & $0.26(3)$ & $-1.16 /-1.94$ \\
\hline
\end{tabular}

ADF stands for Augmented Dickey Fuller ; PP for Phillips Perron; $\tau_{\tau}$ represents the most general model with a drift and trend; $\tau_{\tau}$ is the model with a drift and without trend; $\tau$ is the most restrictive model without a drift and without trend .

Numbers in brackets are number of lags used in the ADF test in order to remove serial correlation in the residuals. When using PP test, numbers in brackets represent the truncation lag parameter.

Tests for unit roots have been carried out on E-VIEWS 3.0.

Table 2. Augmented Dickey-Fuller and Phillips Perron Unit Root Tests (first differences)

\begin{tabular}{ccccc}
\hline Statistics & $\Delta \log Y$ & $\Delta \log$ TOUSA & $\Delta \log q$ & $\begin{array}{c}\text { Critical values } \\
90 \% \text { and } 95 \%\end{array}$ \\
\hline$\tau_{\tau(\mathrm{ADF})}$ & $-3.25(1)$ & $-5.70(2)$ & $-4.79(2)$ & $-3.15 /-3.46$ \\
$\tau_{\mu(\mathrm{ADF})}$ & $-3.23(1)$ & $-5.76(2)$ & $-4.73(2)$ & $-2.58 /-2.89$ \\
$\tau_{(\mathrm{ADF})}$ & $-1.79(1)$ & $-5.27(2)$ & $-4.74(2)$ & $-1.16 /-1.94$ \\
$\tau_{\tau(\mathrm{PP})}$ & $-3.24(3)$ & $-14.27(3)$ & $-8.74(3)$ & $-3.15 /-3.46$ \\
$\tau_{\mu(\mathrm{PP})}$ & $-3.27(3)$ & $-14.35(3)$ & $-8.74(3)$ & $-2.58 /-2.89$ \\
$\tau_{(\mathrm{PP})}$ & $-1.66(3)$ & $-13.82(3)$ & $-8.79(3)$ & $-1.16 /-1.94$ \\
\hline
\end{tabular}

Symbol $\Delta$ represents the corresponding variable in first differences. 


\section{METHODOLOGY AND RESULTS}

This paper uses Johansen's cointegration methodology, which is suitable for estimation purposes when the variables are non-stationary, and particularly when they are $I(1)$ variables. It suggests likelihood ratio tests which enable us to test for the order of cointegration and for restrictions on the variables of the cointegrating vector. A comprehensive description of estimating cointegrating vectors and testing hypothesis can be found in Johansen $(1988,1995)$ and Johansen and Juselius (1990, 1992). This approach estimates long-run or cointegration relationships between non-stationary variables using a maximum likelihood procedure which tests for the number of cointegrating relationships and estimates the parameters of those cointegrating relationships. The method uses a statistical model that is a $p$-dimensional VAR process of order $K$, where $p$ is the number of variables. The general vector autoregression is,

$\mathbf{y}_{t}=a+\sum_{i=1}^{3} \phi_{i} Q_{i t}+\sum_{i=1}^{k} \pi_{i} \mathbf{y}_{t-i}+\varepsilon_{t}$

where either $\mathbf{y}_{t}$ and $\mathbf{y}_{t-i}$ include the logarithms of the three variables $(Y$, TOUSA, $q) ; a$ is the intercept, $Q_{i t}$ represents the deterministic seasonal (quarterly) dummies, and $\varepsilon_{t}$ is a disturbance term independently and identically distributed with zero mean and constant variance.

The Johansen estimation method is based on the error correction representation of the general vector autorregression. Thus, equation 2 can be reparameterised in error correction form as:

$$
\Delta \mathbf{y}_{t}=a+\sum_{i=1}^{3} \phi_{i} Q_{i t}+\sum_{i=1}^{k-1} \Gamma_{i} \Delta \mathbf{y}_{t-i}+\Pi \mathbf{y}_{t-k}+\varepsilon_{t}
$$

The number of cointegrating vectors that exist among the variables is determined by estimating the rank of the matrix П. Johansen (1988) proposes two likelihood ratio tests for the cointegration rank, a maximum eigenvalue test and a trace test. Results of both tests will be shown in next section.

The next step is then to specify our multivariate model and apply the Johansen methodology. This approach estimates long-run or cointegrating relationships between non- 
stationary variables using a maximum likelihood procedure which tests for the number of cointegrating vectors and estimates their parameters.

The results of cointegration tests are reported in Table 3. The two test statistics, maximum eigenvalue ( $\lambda \mathrm{MAX})$ and trace, are presented, where $\lambda$ MAX tests for at most $r$ cointegrating vectors against the alternative of exactly $\mathrm{r}+1$ cointegrating relationships, while Trace tests for at most $r$ cointegrating vectors against the alternative of at least $r+1$ vectors.

A number of lags for each of the variables and countries have been included in order to capture the short-run dynamics of the model. ${ }^{11} \mathrm{Up}$ to four lags have been tried for each equation, which should provide a sufficient representation of the process generating the data given that we are dealing with quarterly time series. According to the Akaike Information Criteria (AIC), this is the lag length of the level VAR system that has been determined by minimising it. $^{12}$

Table 3. Johansen Maximum Likelihood Cointegration Tests (1975Q1-1997Q1)

\begin{tabular}{|c|c|c|c|c|}
\hline $\begin{array}{l}\text { r: number of } \\
\text { cointegrating } \\
\text { vectors (null } \\
\text { hypothesis) }\end{array}$ & $\lambda$ MAX & Trace & $\begin{array}{c}\text { Critical values } \\
95 \% \text { and } 90 \% \\
(\lambda M A X)\end{array}$ & $\begin{array}{c}\text { Critical values } \\
95 \% \text { and } 90 \% \text { (Trace) }\end{array}$ \\
\hline $\mathrm{r}=0$ & $30.14 *$ & $40.93 *$ & 20.97/18.60 & $29.68 / 26.78$ \\
\hline $\mathrm{r} \leq 1$ & 10.76 & 10.79 & $14.07 / 12.07$ & $15.41 / 13.32$ \\
\hline $\mathrm{r} \leq 2$ & 0.029 & 0.029 & $3.76 / 2.69$ & $3.76 / 2.68$ \\
\hline \multicolumn{5}{|c|}{ Parameter Estimates (normalised) } \\
\hline \multicolumn{3}{|c|}{ Variables } & \multicolumn{2}{|c|}{ Cointegrating vector } \\
\hline \multicolumn{2}{|c|}{$\log Y$} & & \multicolumn{2}{|c|}{-1} \\
\hline \multicolumn{3}{|c|}{$\log \operatorname{TOUSA}(+)$} & \multicolumn{2}{|c|}{0.30} \\
\hline \multicolumn{3}{|c|}{$\log q(+)$} & \multicolumn{2}{|c|}{2.85} \\
\hline
\end{tabular}

$\lambda \mathrm{MAX}$ and Trace are the likelihood ratio statistics for the number of cointegrating vectors. Estimation has been performed with MICROFIT 3.0.

* Indicates significance at 5 percent level, critical values are based on Osterwald-Lenum (1992).

In the second panel, $Y$ denotes domestic income, TOUSA, tourism, and $q$, real effective exchange rate. In brackets are the expected signs for TOUSA and $q$. Parameter estimates express different elasticities.

\footnotetext{
${ }^{11}$ In general, economic results are quite sensible with few lags.

${ }^{12}$ Increasing too much the value of $k$ (lag length) may cause over-parameterisation of the model which affects the estimates of cointegrating vectors making it difficult to interpret economically the cointegration relations. On the other hand, setting too small a value of the lag length may distort the size of the tests.
} 
Both $\lambda M A X$ and Trace tests suggest that there is a cointegrating relationship. ${ }^{13}$ It indicates that tourism positively affects Spanish economic growth over time. These results show that single-equation estimation for an increase in tourism can capture the long-run relationship. The existing correlation between economic growth and foreign exchange income from tourism is not spurious.

From the estimates one can infer that the presence of multiplier effects on income are really important. The interpretation of the elasticity of economic growth with respect to tourism should read as follows: a 5 per cent of a sustained growth rate in foreign exchange earnings from tourism would imply an estimated increase of almost 1.5 percent domestic real income in the long run. This is a significant fact since tourism in Spain has never represented, so far, more than 5 per cent of overall Spanish income.

As in most of empirical research about the influence of exports in the economic growth, the external competition has a relevant role when analysing a possible long-run relationship. Therefore, the estimate of the corresponding elasticity would indicate that in general, an increase of the Spanish economy competitivity with regard to industrialised countries would have had significant effects on its economic growth rate in the last three decades.

In order to examine the robustness of the above results one is referred to Table 4 which reports the outcomes of the parameter restriction tests for economic growth, tourism and exchange rate variables. The restriction is that each coefficient of the corresponding variables is zero. This hypothesis is rejected for $Y$, TOUSA and $q .{ }^{14}$ Therefore, all variables are significant at 5 per cent significance level. It should be noted, then, that the combination of those three variables in the model is important for obtaining a reliable long-run relationship. The existence of that link is sustained by the effects that external competition $(q)$ has on Spanish economic growth. In fact, when this variable was excluded, no cointegrating vector was found between economic growth and tourism.

\footnotetext{
13 Trends in the variables and in the DGP were allowed for in estimation, although the results were not practically sensitive to estimation method.

${ }^{14}$ Note that a parameter restriction test is also made on the dependent variable $(Y)$ in order to examine whether it is significant or not, so that it can be either included or excluded from the relationship among the variables of the model.
} 


\section{Chi-squared \\ Parameter restriction \\ test statistic}

$$
\begin{aligned}
& \alpha_{0}=0 \\
& \alpha_{1}=0 \\
& \alpha_{2}=0
\end{aligned}
$$

The critical value with one degree of freedom at 5 per cent significance level is 3.84

\section{CONCLUDING REMARKS}

As in the export-led growth literature the relationship between economic growth and international tourism has been examined. Since the variables included in the model are nonstationary and present a unit root, the Johansen technique has been applied. This methodology has allowed to obtain a cointegrating relationship among the variables. These variables represent indicators of Spanish economic growth, international tourism income and external competitivity. The cointegration results provide evidence of the existence of a unique cointegrating vector. Therefore, the interpretation of its estimates should be straightforward. The analysis shows, then, that a long-run stable relationship between economic growth and tourism expansion exists.

As expected, the earnings from international tourism affect positively the Spanish economic growth. The strong impact of tourist activity, according to the magnitude of the estimated parameter would reveal the existence of important long-run multiplier effects. These results would support the main predictions made by those models which treat tourism as both a non-traded good and a service. Contrary to what the traditional export-led growth literature predicts, tourism-led growth is not specific of developing countries which base their foreign exchange earnings on the existence of a comparative advantage in certain sectors of the economy. A more generalised impact is ascribed to the tourist activity. It affects to most 
part of tertiary and non-durable goods consumption sector. On the other hand, it seems like possible effects that reduce welfare from an increase of domestic prices (Hazari and $\mathrm{Ng}$, 1993) would be more than compensated through positive effects on the country's overall welfare.

In addition to this, the convergence of those two variables (income and tourism earnings) is sustained by the inclusion of external competitivity. This variable has been proved to be also fundamental in the rapid growth of the Spanish economy over time.

Finally, the significant impact of tourism on the Spanish economy justifies the necessity of public intervention aimed to, on the one hand, promote and increase international tourism demand and on the other hand provide and foster the development of tourism supply. At the same time, a warning on possible dangers derived from underestimating the importance of expenditure in tourist infrastructure, undervaluing financial support toward the efforts of entrepreneurial initiative and minimising the significance of protecting natural and sociocultural resources should be made. 


\section{APPENDIX : DEFINITIONS OF SERIES AND DATA SOURCES}

The empirical analysis considers quarterly data for Spain which cover the first quarter of 1975 up to the first quarter of 1997.

The income variable $(Y)$ is represented by the Spanish real gross domestic product (GDP) . It is measured in 1990 local currency units. Data have been drawn from the International Financial Statistics, published by the International Monetary Fund.

The variable tourism (TOUSA) is defined as Spanish tourism revenues in 1990 domestic currency units. Given the great seasonality that exists for tourism in Spain, it has been proceeded to seasonally adjust the corresponding series. The X11-multiplicative filter has been performed using E-Views 3.0. Spanish tourism series are collected from Boletin Estadístico del Banco de España.

The real effective exchange rate $(q)$ is a weighted index that combines the exchange rates between a currency in particular and the currencies of industrialised countries (partner and/or competitor countries). It is adjusted for relative movements in labour unit costs and expressed on 1990 year base. Defined as units of domestic currency per unit of foreign currency, an appreciation of the real effective exchange rate is reflected by a decrease of the index and a depreciation by an increase of the index. Data on real effective exchange rates were also taken from the Boletín Estadístico del Banco de España. 


\section{REFERENCES}

Ahmed, J. and Kwan, A.C.C. (1991) Causality between exports and economic growth, Economics Letters, 37, 243-248.

Bhagwati, J. and Srinivasan, T. (1979) Trade policy and development, in R. Dornbusch and J. Frenkel, eds, International Economic Policy: Theory and Evidence (Johns Hopkins University Press, Baltimore), 1-35.

Dickey, D. A. and Fuller, W. A. (1979) Distribution of the estimators for autorregressive time series with a unit root, Journal of the American Statistical Association, 74, 427-431.

Dickey, D. A. and Fuller, W. A. (1981) Likelihood ratio statistics for autoregressive time series with a unit root, Econometrica, 49, 1057-1072.

Engle, R. F. and Granger, C. W. J. (1987) Cointegration and error correction: representation, estimation, and testing, Econometrica, 2, 251-276.

Granger, C. W. J. and Newbold, P. (1974), Spurious regressions in econometrics, Journal of Econometrics, 2, 111-120.

Hazari, B. R. and Ng, A. (1993) An analysis of tourists' consumption of non-traded goods and services on the welfare of the domestic consumers, International Review of Economics and Finance, 2, 3-58.

Hazari, B.R and Sgro P.M.(1995) Tourism and growth in a dynamic model of trade. The Journal of International Trade and Economic Development, 4, 253-256.

Helpman, E and Krugman, P. (1985) Market structure and foreign trade (MIT Press, Cambridge).

Jin, C.J. (1995): Export-led growth and the four little dragons. The Journal of International Trade and Economic Development, 4, 203-215.

Johansen, S. (1988) Statistical analysis of cointegrating vectors, Journal of Economic Dynamics and Control, 12, 231-54. 
Johansen, S. (1995) Likelihood-based inference in cointegrated vector autorregressive models, Oxford University Press Incorporated, New York.

Johansen, S. and Juselius, K. (1990), Maximum likelihood estimation and inference on cointegration - with applications to the demand for money, Oxford Bulletin of Economics and Statistics, 52, 169-210.

Johansen, S. and Juselius, K. (1992) structural tests in a multivariate cointegration analysis of the PPP and the UIP for UK, Journal of Econometrics, 53, 211-244.

Komiya, R. (1967) Non-traded goods and the pure theory of international trade, International Economic Review, 8, 132-152.

Krueger, A. (1980) Trade Policy as an input to Development, American Economic Review, 70, 188-292.

Kwan, A. C. C. and Cotsomotis, J. (1991) Economic growth and the expanding export sector: China 1952-1985, International Economic Review, 5, 105-117.

McKinnon, R. (1964) Foreign exchange constrain in economic development and efficient aid allocation, Economic Journal, 74, 388-409.

Osterwald-Lenum, M. (1992) A note with quantiles of the asymptotic distribution of the maximum likelihood cointegration rank test statistics, Oxford Bulletin of Economics and Statistics, 54, 461-472.

Padilla, R. (1988) La demanda de servicios turísticos en España, Investigaciones Económicas, 12, 135-157.

Phillips, P. C. B. (1986) Understanding spurious regression in econometrics, Journal of Econometrics, 33, 311-340.

Phillips, P. and Perron, P. (1988) Testing for a unit root in time series regression, Biometrica, 75, 333-346.

Sinclair, M.T. and Sutcliffe, C.M.S.(1980) The measurement of seasonality within the tourist industry: an application to tourist arrivals in Spain. Applied Economics, 12, 429-441. 
Sinclair, M.T. and Sutcliffe, C.M.S. (1982) Keynesian income multipliers with first and second round effects: an application to tourism expenditure. Oxford Bulletin of Economics and Statistics, 44, 321-338.

Thornton, J. (1997) exports and economic growth: evidence from 19th century Europe, Economics Letters, 55, 235-240.

Valenzuela, M. (1988) Spain: the phenomenon of mass tourism, in Tourism and Economic Development: Western European Experiences, Williams, A.M. and Shaw, G. (eds), New York, 39-57.

$\mathrm{Xu}, \mathrm{X}$. (1996) On the causality between export growth and GDP growth: an empirical reinvestigation, Review of International Economics, 4, 172-184. 